\author{
Petre Comșa \\ Valahia University, Targoviste, Romania \\ e-mail: comsa.petre@gmail.com \\ Costea Munteanu \\ Bucharest University of Economic Studies, Romania \\ e-mail: costea_munteanu@yahoo.com
}

\title{
An Interdisciplinary Perspective on the Relationship between Ethics and Today's Capitalism
}

\begin{abstract}
The paper begins by emphasizing the fact that, on a historical scale, one can have several views of the relationship that has existed over time between ethics and capitalism, namely: missionary, 'Nietzschean', critical, and 'regulatory'. It is argued that, nowadays, the capitalization of the contributions supplied, over time, by the four views embraces the form of two modern diametrically opposed perspectives, i.e.: on the one hand, there is the interpretation given by the neo-classical school of thought (mainstream economics) and, on the other hand, it comes to the interpretation given by the Austrian praxeological economic school (libertarian economics). The emphasis of the analysis is put on the assertions developed by the last one, libertarian thinking, that insists on the necessity to operate with a well-defined distinction between the legal level of the matter, the ethical level and the moral one. At the core of the libertarian analysis there is the understanding of the capitalist system being naturally impregnated by ethical values. And this intrinsic ethical nature of capitalism is organically bound to the sphere of the ownership-type relationship.

In line with the understanding of the economic system, based on the institutions of the free market as representing ethical capitalism per se, the paper argues that the realities of the world today show governmental interventionism as a main factor that supports non-ethical economic behaviour. As a consequence, the more limited government intervention is, the greater the chance of ethical capitalism, that is, voluntary, non-conflictual and non-aggressive economic market relationships. Under such conditions, a 'minimal state' institutional arrangement (that is, the legitimate use of power by the state is limited to preventing fraud or the use of force; it does
\end{abstract}


not include the power to tax or to confiscate property) is the basic condition for the existence of an ethical capitalism that works, which is to say that the chance of an economic system based on ethical values stands in people's willingness to be part of such an evolution in society that aims to minimise the role of the state.

Further, the paper argues that any historical analysis on how societies asserted such a willingness outlines the expression of a secular and unshaken option for growing rather than diminishing state involvement in the economy. It is about people's perennial preference for the state, namely for the organization of society based on state interventionism (respectively, their preference for the coercive order imposed by the state authorities, order based, through its own nature, on the subjugation of private property and the aggression against individual freedom), with a preference for the government intervention over the organization of a society based on free market functioning (which is equivalent, in fact, to their rejection of a voluntarily and spontaneously non-violent order, based on the observance of private property and individual freedom, brought about by the free functioning of markets).

In the last part of the paper there are put forward for discussion the possible explanations for this perennial preference for non-ethical capitalism, the analysis focusing on two directions: firstly, on that of social ontology; and then, on that of human psychology.

Keywords: neoclassical economics, libertarian economics, natural law, institutionalized aggression, state preference, private property order

JEL Classification: A13, P17, P26, Z13

\section{Historical views on the relationship between ethics and capitalism}

On a historical scale, one can talk about several views of the relationship that worked over time between ethics and economy (more precisely, between ethics and the capitalist system), namely: the missionary, 'Nietzschean', critical and 'regulatory'. ${ }^{1}$

Regarding the first view, the missionary, we have to specify from the beginning that the notion of 'missionary' is generally associated with the liberal tradition. 'Missionaries conceive capitalism as a profound and ethical system in its nature,

\footnotetext{
${ }^{1}$ M.-L. Djelic, How has capitalism lost its soul: From the protestant ethics to the "robbery barons", [in:] Ethical frontiers of capitalism, eds. D. Dăianu, R. Vrânceanu, Polirom Printing House, Iasi, Romania 2006, p. 61.
} 
being thus a condition for the development and consolidation of a moral behaviour,' ${ }^{2}$ thus it can be said that missionaries are inclined to believe and support the capitalist market being closely connected both with political freedom and democracy, and also with moral and social progress.

The second view is named 'Nietzschean', in the sense that it places capitalism beyond - or before - ethics. There are a number of analysts who believe that, in this case: '(...) the intellectual inspiration has its roots in the classic liberalism, but the accent is put on the "natural" feature (namely, pre-historical, pre-social, and thus preethical) of the capitalist logic. ${ }^{3}$ From this results a double consequence: on the one hand, as a natural order, capitalism is fundamentally ineluctable; and, on the other, the boundaries between ethics and capitalism have to be unequivocal. Thus, the aim of a business is to bring about profit and increase wealth. The ethical concerns have to be placed beyond the capitalist logic and the sphere of economy, so as not to disturb and influence the dynamics of the natural (economic) forces. ${ }^{4}$ And we think that, given all these things, there is no risk in considering that, under the 'Nietzschean' perspective, capitalism represents an amoral economic order which can co-exist without difficulties along with different types of socio-political systems.

The third vision, the critical one, suggests an understanding of the ethics-capitalism relationship under totally different terms, compared with the views promoted by the previously discussed perspectives. The critical perspective considers capitalism to be a deeply immoral system by nature. It is the vision that considers that the individual's greed and power make up the motoric forces of the capitalist logic, '(...) the consequence being (...) exploitation. ${ }^{\prime 5}$ In turn, exploitation can have different forms and can materialize as an implacable reality of the social dynamics at different levels: the person, social classes, ethnic groups, religious denominations, peoples. Consequently, the supporters of such a critical perspective back up that the necessary prerequisite for the existence of a moral world is the overcoming of the capitalist logic; and this thing can be achieved only through a revolutionary programme. It is true that such a vision has lost a lot of its power and representativity during the 90s, concurrently with the collapse of communism. However, '(...) the consequences of globalization for certain groups and countries confronted with the multiplication of scandals within the great corporations at the core of the capitalist system, have lately resuscitated this perspective, at least at the level of some segments of the anti-globalization movement. ${ }^{6}$

Finally, the last of the specified historical views, the one named 'regulatory', has at its foundation the concept according to which the capitalist system is not ethical or self-regulatory by its own nature. Nevertheless, for the promoters of this view, capitalism can - and has to - be associated with efforts of regulation, with the

\footnotetext{
${ }^{2}$ Ibidem.

${ }^{3}$ Ibidem.

${ }^{4}$ M. Friedman, Capitalism and Freedom, Chicago University Press, Chicago 1962, cited in: M.-L. Djelic, op. cit., pp. 61-62.

${ }^{5}$ The idea is shown and analysed in: Djelic, op. cit., p. 62.

${ }^{6}$ Ibidem.
} 
aim of creating the proper conditions for certain moral conduct and interactions. ${ }^{7}$ According to this perspective, ethics can be defined as an aggregate of conduct codes existing either at local level (or, generalizing, at the national one), or as a set of universally applicable norms. ${ }^{8}$ Under the first meaning, the effort to regulate is supposed to be controlled by the state or national political institutions. ${ }^{9}$ The second meaning requires a different regulatory framework, in the sense that, although here again the state has a role, it is not the single actor: the organizations from the semipublic sector with a transnational feature, as well as (sometimes) the transnational corporations themselves, have something to say regarding the regulatory effort. ${ }^{10}$

\section{The neoclassical interpretation of the ethics-capitalism rela- tionship}

It makes sense to say that, overtime, the four views actually co-existed, precisely under the conditions where each one represented a different theoretical and practical standpoint of the interpretation of the ethics-capitalism relationship. As is rightfully noticed in the literature, ${ }^{11}$ each of the above mentioned perspectives offers empirical arguments that cannot be neglected in support of the promoted theoretical point of view, even if the sets of data used, and also the methods of collecting them, would prove to be significantly different.

In sum, the capitalization of the contributions supplied, over time, by the four views embraces nowadays, in our opinion, the form of two diametrically opposed approaches, as follows: on the one hand, there is the neoclassical school of thought (mainstream economics), which promotes interventionist-type capitalism - in other words, a capitalist system centred on the state and based on the claimed necessity and legitimacy of government intervention aimed at correcting so-called 'market failures'; and on the other hand, there is the Austrian praxeological economic school of thought (libertarian economics), which advocates market-type capitalism - as an economic system where inter-personal relationships are based on the observance of the legitimate property rights on resources, a system that declares and supports the individual's freedom to use the owned resources in ways he/she considers to be most favourable, without the coercive interference of the bureaucratic machinery of the state.

In this section we shall briefly pay attention to the specific interpretation offered by mainstream economics to the ethics-capitalism relationship, while in the following section some characteristics of the libertarian approach will be emphasized.

\footnotetext{
${ }^{7}$ Making Globalization Good, ed. J. Dunning, Oxford University Press, Oxford, New York 2003, cited in: M.-L. Djelic, op. cit., p. 62.

${ }^{8}$ H. Kung, An Ethical Framework for the Global Market Economy [in:] Making Globalization Good, ed. J. Dunning, Oxford University Press, Oxford, New York 2003, cited in: M.-L. Djelic, op. cit., p. 62.

${ }^{9}$ S. Clegg, E. Ibarra-Colado, L. Bueno-Rodriques, Global Management: Universal Theories and Local Realities, Sage, London 1998, cited in: M.-L. Djelic, op. cit., p. 62.

${ }^{10}$ Transnational Regulation in the Making, eds. M.-L. Djelic, K. Sahlin-Anderson, Cambridge University Press, Cambridge, New York 2005.

${ }^{11}$ M.-L. Djelic, op. cit., p. 63.
} 
For mainstream economists, historically speaking, capitalism began as a system with a strong moral foundation, eventually 'losing its soul', somehow, as a result of the combined action of different factors. We shall not analyse here these factors, instead we shall point out that for these economists, the present-day consequence of such an evolution is that the capitalist system has become today amoral and non-ethical (rather than immoral and unethical). ${ }^{12}$ In consequence, most mainstream economists consider that '(...) any endorsement of capitalism with an ethical program needs a regulating intervention.' (emphasis added) ${ }^{13}$ This gives us the opportunity to say that, in its substance, the modern mainstream interpretation preserves and strengthens the historical vision based on the crucial role of regulation (in mediating the relationship between ethics and capitalism).

Following this line of argument, neoclassical economists believe that the decision to act in a regulatory manner is, after all, a political one - and this in the strictest sense of the word. And such a decision has to take into account the priorities of certain human and social communities, represented by national states or larger transnational entities, such as the European Union. Ultimately, we believe that the modern mainstream message regarding the relationship between ethics and capitalism can be synthesized as follows: ${ }^{14}$ the 'iron cage' of capitalism cannot be seen as a spontaneous ethical order that adjusts itself, as long as the possible co-existence of today's capitalism with a certain ethical programme requires regulatory intervention.

\section{The libertarian interpretation of the ethics-capitalism relationship}

Unlike the mainstream approach, which promotes the interventionist-type capitalism, the libertarian view promotes free market capitalism.

Against this background, it should be mentioned that the problem of the interpretation of the relationship between ethics and capitalism maintains unaltered the general radical differentiations between the two views (briefly discussed above). Thus, as we have already seen, the mainstream approach asserts with no doubt the amoral and non-ethical characteristic of capitalism, for which reason any association with an ethical programme needs regulatory (governmental) intervention. By contrast, the libertarian approach starts from the explicit recognition of the intrinsic ethical feature of the economic processes that give substance to the capitalist system.

Thus libertarians reject the ambiguous position of neoclassical mainstream economists who, on the one hand, state explicitly that the economics should be concerned exclusively with the study of 'facts' and not with that of (ethical) value judgments, and on the other hand, however, often engage in arguments using implicit

${ }^{12}$ M.-L. Djelic, op. cit., p. 62.

${ }^{13}$ Ibidem.

${ }^{14}$ See also: Ibidem, p. 63. 
(ethical) value judgments. For libertarians, the attractiveness to obliterate the ethical characteristic of certain standpoints comes from the fact that the assertions which are 'descriptive', 'positive' or 'neutral regarding the values' seem to give some kind of scientific respectability; such a researcher is considered 'a lucid observer of the facts' rather than a 'moralist wolf.' 15

The most important libertarian thinkers that significantly contributed to debates on the juridical, ethical, and moral issues in economics are Murray Rothbard and Hans-Hermann Hoppe. The first explained in the most systematic way his vision on these topics in his brilliant Ethics of Liberty, ${ }^{16}$ while the second one put forth his ideas in The Economics and Ethics of Private Property. ${ }^{17}$

We can say that the libertarian discourse on the intimate connection which operates between ethics and capitalism starts from the following question: ultimately, are there bad, poor, harmful laws ${ }^{18}$ A consistent negative answer implies, in the libertarians' opinion, resorting to an extreme positivist position: any rule that succeeds in passing through a regulatory body and is adopted, by the very fact that it becomes a law means it is good, that is, complete and useful. While, on the other hand, an affirmative answer to this question would imply, in the libertarians' understanding, the acceptance of three conceptually distinct levels of discussion.

At the beginning there would be the juridical level. It takes into account the positive law and, within it, individuals' actions are divided into legal and illegal. And,

(...) although the attribute of a certain action of a being legal is, generally speaking, auspicious - because it means that the respective action complies with rules (while the illegal one is perceived as inauspicious - there is cheating) - an overlap of 'good equals legal' and 'illegal equals bad' would naturally seem to be completely rejected by the contemplation of a situation such as that of the so-called final solution to the 'Jewish problem' during Hitler's time. Although the applied treatment was legally justified, common sense seems to definitely reject that action as being somehow justified. An example in another sense would be black market employment (with wages below the minimum legal levels permitted in the economy), which although illegal, can be in many cases the only chance of employment for a certain category of workers (mostly unqualified ones). ${ }^{19}$

The second level of discussion is the ethical one. It consists of general principles of law, more specifically of natural law. At this level, the libertarians take into account a corpus of principles and concepts that are the basis from where the more practical and pragmatic activity of enactment of legislation begins (that belonging to the above mentioned level). Therefore, it can be said that:

\footnotetext{
${ }^{15}$ See: M.-V. Topan, The Entrepreneur in the International Firm. A Theorizing in the Austrian School Tradition, The Bucharest University of Economic Studies Press, Bucharest 2013, p. 230.

${ }^{16}$ See: M.N. Rothbard, Ethics of Liberty, New York University Press, New York and London 1988 (first edition in 1982).

${ }^{17}$ See: H.-H. Hoppe, The Economics and Ethics of Private Property. Studies in Political Economy and Philosophy, The Ludwig von Mises Institute, Auburn, Alabama 2006 (first edition in 1993).

${ }^{18}$ The text below follows the ideas developed in M.-V. Topan, op. cit., pp. 231-237.

${ }^{19}$ Ibidem.
} 
(...) the existence of this level offers the possibility to meaningfully, essentially and systematically criticize the legislation in force and the process of enactment as a rational and non-arbitrary process. Under an ideal situation, this level would appoint a kind of the greatest common measure of all the existing legal systems. All legal provisions of all legal systems would have to comprise only the elements that are not contradictory to the general principles of the natural law level. Another way to put the problem would be that at this level there are under consideration the principles of justice in the most fundamental sense, if one can say so. ${ }^{20}$

At this ethical level, actions are divided into just and unjust, by reference to a third party. More than that, when the legal rules and provisions are consistent with the ethical level, we can say that we have defined the sphere of actions for which counteraction (or for subsequently obtaining just restitution) is legally allowed to use force (which implicitly has a strictly defensive, restitutive characteristic).

The third and the last level of discussion is the moral one. Here, the actions are divided into virtuous (moral/honest) and vicious (immoral/dishonest). The fundamental distinction is that:

(...) the moral level shows virtually unlimited possibilities to doing good deeds, virtuous actions, possibilities that go from the minimum threshold designated by the ethical level (namely, not to transgress the liberty and legitimate sphere of the other - in other words, the private legitimate property) to the maximum limit of self-sacrifice for the sake of the other. On the negative side of the things, there is implicitly the fact that unjust (non-ethical) actions are also immoral; but immorality has a larger horizon, containing in it a great number of actions that in a limited way (that is, ethically) are just. ${ }^{21}$

In this context, it is extremely important to understand that for the sanction of immoral facts, force is not allowed to be used, but possibly only the non-aggressive public scorn such as a boycott. In other words, 'not to do what at the ethical level would be required not to be done' is a duty, and the failure of non-fulfilment entails justice correcting the non-ethical conduct even by force; instead, 'not to do what at the moral level would be required to be done' is just a matter of impudence/shame, of thin, weak virtue.

In brief, one can say that central to the libertarian approach of the relationship that operates between ethics and capitalism is a well-defined distinction between aggression and non-aggression. In terms of our earlier discussion, libertarians place this fundamental distinction on the second level (the ethical one), with the specification that in a judicial well organized order, the legal/illegal categories overlap the non-aggressive/aggressive ones.

Moreover, it is worthwhile mentioning that in his work Ethics of Liberty, Rothbard mentions that, from a legal point of view, the distinction of aggression/nonaggression is strictly disjointed, the third part being excluded. Based on this distinction, one can say that any economic agent could be - at a given time and related to a certain action of him - in one of the following circumstances: ${ }^{22}$

${ }^{20}$ Ibidem, pp. 231-232.

${ }^{21}$ Ibidem, p. 232 (emphasis in original).

${ }^{22}$ Ibidem, pp. 234-235. 
(1) either as an aggressor, in which case, in terms of law, the question of victim compensation must be solved, even with the legitimately use of force/coercion against the aggressor;

(2) or as a non-aggressor, in which case, in terms of law, the economic agent is 'off charges', and this regardless of his/her moral stature. Accordingly, no matter of how detestable the agent is in moral terms (in the sense of 'callous', 'thick-skinned' fellow), the only possible measures against him could take the form of personal boycott and the refusal of later social interaction with the involved one: in the case of me being a client I shall not buy any longer; if I am a business partner, I shall not conclude further contracts; if I am an employee, I shall resign and consider becoming employed by the competitor.

In our opinion, the really important fact for our discussion here is that Rothbard uses, for defining aggression/non-aggression, a theory of property, more precisely the classic liberal one of Lockean origin. According to classics, the only legitimate ways of getting properties is considered to be one of the following: the original appropriation or homesteading (namely, taking over resources that nobody owned before), production, voluntary exchange, as well as unilateral transfers (the type of donations, presents, heritages or sponsorships).

In terms of economic ethics analysis, the consequences of the above mentioned considerations are peremptory: the non-aggressor gains wealth, properties, goods, services etc. only through just and honest ways, namely ethical ones. The aggressor abuses the resources that others have thus gained, behaving unethically. In other words, the non-aggressor is the one that does not transgress the legitimate private property of others, and aggressor is the one that defies it. ${ }^{23}$ That is equivalent to saying that the ethical dimension of economic behaviour is defined in terms of observing vs. violating the property rights.

An in-depth analysis reveals that the libertarian/Rothbardian approach to economic ethics allows a more nuanced understanding of the interactions between the participants in the market. In this respect:

The interpersonal conflict is thinkable only in a world of scarcity and appears when two wills seek to 'absorb' the same resource (profit share; the worker's energy and his leisure time; a spot of nature) to use each in a different way - the respective uses being mutually exclusive. The property rights theory has as a stake to explain the principles of the eradication/solving the conflicts through the allotting of exclusive rights on resources to a single will: the owner (who becomes implicitly the 'rightful owner'). ${ }^{24}$

One brief comment we would like to make here: the one who raises the problem of solving the conflicts in this world of scarcity raises implicitly the problem of property, either he/she recognizes it or not. In other words, to approach the economic ethics issues in terms of conflicts related to scarce resources (for instance,

\footnotetext{
${ }^{23}$ See: ibidem, p. 235.

${ }^{24}$ Ibidem.
} 
the conflict employee versus employer regarding an additional facility, let us say a share of the profit, which the first would see included in wages, while the second one sees it included in profits/dividends; or, the conflict entrepreneur/corporation versus client regarding this time also an additional facility - a service, for instance - that the entrepreneur would see distinctly payed, but the client would see it included in the price) is equivalent to approaching them as discussions that have to take place under the terms of property rights. ${ }^{25}$

Trying to summarize what has previously been said, we shall emphasize the following ideas:

(1) in the economic realm, it is ethical that, in the fight with scarcity, economic agents engage voluntarily in a non-aggressive inter-personal relationship with their partners in the market. This is market-type capitalism (mentioned earlier in our paper), and hopefully we are now in a better position to realize that market-type capitalism is by its very nature ethical capitalism;

(2) however, the realities of the world we are living in show that a major obstacle to voluntary and non-aggressive inter-personal market relations is represented by governmental intervention in the functioning of the free market. ${ }^{26}$ This is interventionist-type capitalism (also discussed earlier), and hopefully, again, it now appears evident that this is unethical capitalism;

(3) therefore, it turns out that the less state intervention there is, the greater the ethical capitalism. Under such conditions, the basic condition for the existence of an ethical capitalism that works is a 'minimal state' institutional arrangement, what is equivalent with the affirmation that the chance

\footnotetext{
${ }^{25}$ See also: ibidem, pp. 235-236.

${ }^{26}$ On the one hand, we should bear in mind the fact that the free market is a place where private owners interact voluntarily, non-conflictualy, and non-aggressively. Or, to be more precise, it represents the network of voluntarily exchanges created by them. The market is the network of voluntary transactions/exchanges between owners, between people that exchange property rights. Being voluntary, the exchanges are always favourable for the involved parties, at least $e x$ ante, otherwise they would not have involved themselves voluntarily in the given exchanges.

On the other hand, we have to bear in mind the fact that what properly defines the modern state is its statue of a territorial monopoly on both the regulation and legitimate utilisation of the coercive means of taxation. However, it is not about defensive violence: the idea of regulation and taxation is consonant only with the possibility of institutionalized aggression (namely, the state is the only one allowed to initiate violence for reasons that can be called 'in the public interest'). From this we have what libertarian economists call the self-contradictory ethical characteristic of the modern state. Thus, as long as the only legitimate ways of getting properties are original appropriation, production, trade or unilateral transfers, it is clear that the state does not gain its resources by either of the mentioned ways, but through duties and taxation. Is the state really legitimate in this case, is it an institution of affirmation and preservation of ethical conduct in society?

Surely, the main role of the state is the preservation of the rule of law in society (in the sense of defending the integrity of the property of all peaceful, non-aggressive citizens). And here is the problem under discussion: the state cannot exercise this function without implicitly violating the principles that it has to defend and apply, and this is due to its monopoly on regulation and taxation, a monopoly imposed on its citizens through aggressive force. In other words, resorting to the memorable expression of the libertarian economist Hans-Hermann Hoppe: the state acquires the self-contradictory ethical characteristic of 'expropriating property protector.'
} 
of an economic system based on ethical values stands in people's willingness to enter such a societal evolution which aims at minimizing the state's role.

However, the following question immediately emerges: to what extent do people in today's world have such frame of mind. It is the matter that we shall look at in the following paragraphs.

\section{The preference for the state}

From a historical perspective, a firm secular trend of increasing, and not diminishing, state involvement in the economy can be observed. For example, if at the beginning of the $19^{\text {th }}$ century one can find a limited and a relatively constant level of state involvement (measured by the GDP equivalent of tax collection, the involvement was illustrated by a level of 5 percent), towards the end of the century a trend of steady increase in the percentage of tax collection could be seen, so that by the middle of the $20^{\text {th }}$ century it reached the very high level of 40 percent of GDP. At present, tax collection varies a lot among states, but the level remains, on average, over 40 percent, the current crisis resulting, in fact, in a significant increase of state involvement in the economy (especially due to the measures aimed at controlling the effects of the crisis).

Further, during the period that followed the Second World War, it can be seen that even in the major Western industrialized countries (in addition to the communist bloc countries of those times) the public (collectivized) sector extended its redistribution role to levels reaching 40-60 percent of the total national income produced by those countries.

All these developments testify to an impressive phenomenon: the perennial preference of people for the state. Or more precisely, for a state-centred society, to the detriment of a social organization based on the free market functioning. And even more precisely, for setting the social relationship on unethical grounds.

This state of things can raise a number of provocative questions, such as:

(1) why is state interventionism perceived by people as being the only perennial solution for the smooth running of societies over time?

(2) if the free market economy is so good - as the libertarians assert - why is it not perceived, then, as the real solution?

(3) if governments are bad, why do they have so much power over our world today?

The generally accepted explanation that social science researchers offer to this phenomenon is, to our knowledge at least, that the citizens themselves wish and require this thing, that is, a society based on state interventionism. Otherwise, it is argued, the political personalities and parties that would possibly run for an electoral platform which promises a minimal state would win power and would change the balance in favour of the free market. The fact is that this has not yet happened (the relatively poor results of the poll obtained by the American republican senator 
Ron Paul - an ardent promoter of the libertarian values - in the electoral contest for getting his party investiture to run for the presidential elections in 2012 is, maybe, the most recent illustration in this respect).

In the remaining part of our paper, we shall try to find more articulate answers to the questions raised above. And we shall try to do this by focusing our attention on two distinct levels of questioning: human psychology and social ontology.

\subsection{The human psychology level}

At the level of human psychology, the explanation of the perennial preference of people for the state starts from discovering that people want to be at liberty to make their own choices, and to be free from coercion by others, including indirect coercion through means of persuasion. ${ }^{27}$ However, liberty carries with it responsibility and it seems evident - it is argued - that many people do not want to shoulder the final responsibility for their own actions. Many people are, indeed, afraid to be free. In fact:

The thirst or desire for freedom, and responsibility, is perhaps not nearly so universal as so many post-Enlightenment philosophers have assumed. What share of persons in varying degrees of bondage, from slavery to ordinary wage-salary contracts, really want to be free, with the accompanying responsibility for their own choices? The disastrous failure of 'forty acres and a mule' was followed by the lapse into renewed dependency status for emancipated former slaves in the American south. And the surprising strength of Communist parties in the politics of post-Cold War central and eastern Europe attests to the thirst on the part of many persons 'to be controlled.' 28

In this respect, the human psychology argument claims that the 'afraid to be free' behaviour is akin to that of the child who seeks the cocoon-like protection of its parents, and who may enjoy its liberty, but only within the limits defined by the range of such protection. This comfortable setting is dramatically disturbed when the child becomes an adult, when responsibility must be shouldered independently from the family bounds. Relatively few people are sufficiently strong, as individuals, to take on the full range of liberties and their accompanying responsibilities without seeking some substitute or replacement of the parental shelter ${ }^{29}$ It is what one could call 'the parental syndrome' as one of the psychological factors potentially responsible for people's preference for the state.

Following this idea, it is emphasized that prior to the eighteenth century, to the Enlightenment, and particularly in the West, God, as institutionally embodied in the church (and churches), fulfilled what seemed to be a natural role as the overarching 'parent' who assumed ultimate responsibility for the individual in a last-resort sense, as biological linkages were necessarily lost in the ageing profile. Psychologically,

${ }^{27}$ J.M. Buchanan, Afraid to Be Free: Dependency as Desideratum, "Public Choice" 2005, Vol. 124, No. 1/2, pp. 19-31, doi: 10.1007/s11127-005-4743-2, reprinted in: Policy Challenges and Political Responses: Public Choice Perspectives on the Post-9/11 World, eds. W.F. Shughart II, R.D. Tollison, Springer, 2005.

${ }^{28}$ Ibidem, p. 24.

${ }^{29}$ Ibidem. 
people went about their ordinary lives secure in the feeling that God would clear up any mess they might make, analogous to parents' behaviour toward children. In other words, God, as institutionally embodied, provided order in the lives of all.

However, nascent efforts in post-medieval centuries to establish secular authority independent of the church were clear signals that God was no longer monolithic in the image of one institution. With the passage of time, competing interpretations emerged, and the conflicts among churches came to be intermingled with conflicts among states as representatives of those churches. In the process, secular authority came to be divorced from ecclesiastical authority and assumed an independent status. By the time of the Enlightenment: ' (...) the secular nation-state had almost reached its maturity, and nationalism, the sense of nationhood, was a more or less natural repository for the sentiments of those persons for whom God had died. ${ }^{30}$ For many, the state, as a collectivity, moved into the gap left by the demise of the church's parental role. In this way, during the course of two centuries, the state replaced God as the father-mother of last resort: the individual who sought family-like protection, but who no longer sensed the presence of such protection in the church, or in God so embodied, found a substitute in the collectivity. ${ }^{31}$ The individual could feel that he/she 'belonged' to the larger community and was necessarily dependent on that community.

It is specifically important for the purposes of the discussion here to emphasize that, within these developments, the collectivity - the state - stepped in and relieved the individual of his responsibility as an independently choosing and acting adult. In other words, the state is the subject of a sui-generis 'transfer of responsibility syndrome' from its citizens. In exchange, of course, the state reduces the liberty of the individual to act as he might choose. But the order that the state, as parent, provides may be, for many, well worth the sacrifice of liberty.

As a conclusion, one can consider that people's perennial preference for state intervention can be partially explained in psychological terms, as long as:

(1) people who are afraid to take on independent responsibility that necessarily goes with liberty (the parental syndrome) demand that the state fills the parental role in their lives (the transfer of responsibility syndrome);

(2) they want to be told what to do and when to do it;

(3) they seek order rather than uncertainty;

(4) they seem willing to bear the opportunity costs that such an order brings with.

\subsection{The socio-ontological level}

The explanation on this level of our discussion relies on what some researchers consider to be a widely shared belief in 'the implacable mission of the state. ${ }^{32}$ In this sense, it should be shown that, on the one hand, the majority of people endorse

\footnotetext{
${ }^{30}$ Ibidem, pp. $25-26$.

${ }^{31}$ Ibidem.

${ }^{32}$ E.P. Stringham, J.R. Hummel, If a Pure Market Economy is So Good, Why Doesn't It Exist? The Importance of Changing Preferences versus Incentives in Social Change, "Quarterly Journal of Austrian Economics" 2010, Vol. 13, No. 2, pp. 31-52.
} 
different governmental policies because they really believe that the government should solve the social problems. Only seldom do they also take into account the possibility that the government could bring about these problems, or that its intervention could aggravate them. Nor do they take into account the possibility that voluntary actions could be able to solve many of the so-called failures of the market.

On the other hand, the widespread belief about the mission of the state is accompanied by an equally wide spread belief about the intrinsic weakness of the free market, in the sense that:

(1) the system based on the free market cannot appear or persist as certain people would always have incentives, as well the ability, to use force against the others;

(2) and, even if society did come into being in a perfect libertarian world without any state, groups who were in competition would eventually build up a coercive government;

(3) so in the absence of governmental monopoly on the use of force, groups who were in competition that could co-operate to solve the disputes could just as well conspire to practise coercion;

(4) thus, it is improbable that a libertarian society would survive, and this due to what is considered in the literature to be the so-called 'paradox of cooperation': some people would be able to co-operate to a sufficient degree that they would threaten others with private force or that of a government;

(5) and, even in the event that most people were peaceful, the strongest groups could easily threaten the others, leaving no other possibility for them but to withdraw: although the victims would be better if they were not persecuted at all, they are in a better situation if they tolerate the persecution and do not treat the aggressors the same way, as confrontations are costly.

Accordingly, the above mentioned researchers reached the conclusion that government is inevitable and the preference for the state seems to be rational: 'In the absence of government - or even when a weak government exists - predatory groups will be imposed by force and will create a government in view of getting income and wealth from them [the rest of the population - P.C. \& C.M.]. ${ }^{, 33}$

\section{Some Concluding Remarks}

The prevailing neoclassic vision considers that the capitalist system is, by its very nature, a-ethical (neither ethical, nor unethical, but beyond ethics) and that, as a consequence, the only legitimate form of relationship between a capitalist economy and ethical values is represented by the regulatory intervention of the state.

The opposite vision, the libertarian one, sees the capitalist system as being naturally impregnated with ethical values. And this intrinsically ethical nature of capitalism is embodied by the area of the property relationship. Accordingly, central to

\footnotetext{
${ }^{33}$ R.G. Holcombe, Government: Unnecessary but Inevitable, "Journal of Libertarian Studies" 2007, Vol. 21, No. 1, p. 326.
} 
the libertarian approach is a well-defined distinction between non-aggression and aggression: the non-aggressor is the one that does not transgress the legitimate private property of others, and the aggressor is the one that defies it. That is why the libertarian vision maintains that it is ethical that, in the struggle with scarcity, the economic agents engage themselves in non-conflictual and non-aggressive interpersonal relationships with their partners in the market.

The realities of the world we live in show that the major obstacle to voluntary and non-aggressive inter-personal market relations is represented by governmental intervention in the functioning of the free market. Under such conditions, the basic condition that ethical capitalism effectively works is represented by consistent diminishing of state interventionism. This means that the chance of an economic system based on ethical values lies in people's willingness to join such a societal evolution which aims to minimize the state's role. Historical developments testify to a firm secular trend of increasing, and not diminishing, state involvement in the economy: the perennial preference of people for the state.

In human psychology terms, state preference is due to both 'parental syndrome' (individuals are afraid to take on independent responsibility that necessarily goes with liberty) and 'the transfer of responsibility syndrome' (individuals demand that the state fills the parental role in their lives). In socio-ontological terms, state preference is due to both the belief in the implacable mission of the state and the belief about the intrinsic weakness of the free market.

The inevitable conclusion seems to be that government is inevitable and people's preference for the state is rational. Nevertheless, simply because libertarianism (the non-statal society) is not yet triumphant anywhere in our world does not mean that the fight for it is pointless and unimportant. History offers many examples when a change in preferences of a large enough number of people resulted in significant changes in the field of politics. So, libertarianism has no need to persuade 100 percent of the people to support free market, ethical capitalism; in exchange (and here we follow Murray Rothbard's ideas) libertarianism (and, in fact, any system) has the need to be sustained by a certain critical mass. Thus, when there is a sufficient number of people to sustain a free market society and to withdraw their support for the government, the ability of the potential predators to create a government would be diminished, and the possibility of a functional non-governmental society will no longer be a utopia. It follows the importance of changing public opinion and people's social preferences. Critical in this respect will be education and persuasion: force or coercion are implacably inefficient.

\section{References}

Buchanan J.M., Afraid to Be Free: Dependency as Desideratum, "Public Choice" 2005, Vol. 124, No. 1/2, pp. 19-31, doi: 10.1007/s11127-005-4743-2, reprinted in: Policy Challenges and Political Responses: Public Choice Perspectives on the Post-9/11 World, eds. W.F. Shughart II, R.D. Tollison, Springer, 2005. 
Clegg S., E. Ibarra-Colado, L. Bueno-Rodriques, Global Management: Universal Theories and Local Realities, Sage, London 1998, cited in: M.-L. Djelic, How has capitalism lost its soul: From the protestant ethics to the "robbery barons" [in:] Ethical frontiers of capitalism, eds. D. Dăianu, R. Vrânceanu, Polirom Printing House, Iasi, Romania 2006.

Djelic M.-L., How has capitalism lost its soul: From the protestant ethics to the "robbery barons" [in:] Ethical frontiers of capitalism, eds. D. Dăianu, R. Vrânceanu, Polirom Printing House, Iasi, Romania 2006.

Friedman M., Capitalism and Freedom, Chicago University Press, Chicago 1962, cited in: M.-L. Djelic, How has capitalism lost its soul: From the protestant ethics to the "robbery barons" [in:] Ethical frontiers of capitalism, eds. D. Dăianu, R. Vrânceanu, Polirom Printing House, Iasi, Romania 2006.

Holcombe R.G., Government: Unnecessary but Inevitable, "Journal of Libertarian Studies" 2007, Vol. 21, No. 1, p. 326.

Hoppe H.-H., The Economics and Ethics of Private Property. Studies in Political Economy and Philosophy, The Ludwig von Mises Institute, Auburn, Alabama 2006 (first edition in 1993).

Kung H., An Ethical Framework for the Global Market Economy [in:] Making Globalization Good, ed. J. Dunning, Oxford University Press, Oxford, New York 2003, cited in: M.-L. Djelic, How has capitalism lost its soul: From the protestant ethics to the "robbery barons" [in:] Ethical frontiers of capitalism, eds. D. Dăianu, R. Vrânceanu, Polirom Printing House, Iasi, Romania 2006.

Making Globalization Good, ed. J. Dunning, Oxford University Press, Oxford, New York 2003, cited in: M.-L. Djelic, How has capitalism lost its soul: From the protestant ethics to the "robbery barons" [in:] Ethical frontiers of capitalism, eds. D. Dăianu, R. Vrânceanu, Polirom Printing House, Iasi, Romania 2006.

Rothbard M.N., Ethics of Liberty, New York University Press, New York and London 1988 (first edition in 1982).

Stringham E.P., J.R. Hummel, If a Pure Market Economy is So Good, Why Doesn't It Exist? The Importance of Changing Preferences versus Incentives in Social Change, "Quarterly Journal of Austrian Economics" 2010, Vol. 13, No. 2, pp. 31-52.

Topan M.-V., The Entrepreneur in the International Firm. A Theorizing in the Austrian School Tradition, The Bucharest University of Economic Studies Press, Bucharest 2013.

Transnational Regulation in the Making, eds. M.-L. Djelic, K. Sahlin-Anderson, Cambridge University Press, Cambridge, New York 2005. 